UDC $57.042+616-006.446 .3$

\title{
EFFECT OF COMBINED ARGINASE AND NITRIC OXIDE DONOR TREATMENT ON NORMAL AND LEUKEMIC CELLS IN VITRO
}

\author{
O. I. Chen ${ }^{1,2}$, M. L. Barska ${ }^{1}$, L. S. Lynivi, \\ N. I. Igumentseva ${ }^{1}$, O. I. Vovk ${ }^{1}$, N. O. Sybirna ${ }^{1,2}$, O. V. Stasyk ${ }^{1 *}$ \\ 1 Institute of Cell Biology, NAS of Ukraine, 14/16, Drahomanov St., Lviv 79005, Ukraine \\ ${ }^{2}$ Ivan Franko National University of Lviv, 4, Hrushevskyi St., Lviv 79005, Ukraine \\ *e-mail: stasyk@cellbiol.Iviv.ua
}

Arginine deprivation has been recently suggested as a therapeutic approach against difficult to cure blood cancers. Herein, we investigated for the first time the combined effect of exogenous nitric oxide (NO) donor and recombinant human arginase (rhARG) as arginine-depleting agent on viability of several human leukemic cell lines and normal peripheral blood lymphocytes (PBL). We found that exogenous NO donor, sodium nitroprusside (SNP), at physiologically compatible dose did not counteract but augmented rhARG-mediated pro-apoptotic effect of arginine depletion in leukemic cells but not in resting lymphocytes. Thus, we hypothesize that NO deficiency resulting from arginine deprivation is not the primary cause of high leukemic cells sensitivity to the action of rhARG. The results of this study further support the notion that not arginine catabolism but other cell response mechanisms must be involved in determining cell fate upon arginine restriction. SNP or alternative NO donors can be proposed as components of metabolic anti-leukemia therapy based on arginine deprivation.

Keywords: recombinant arginase, nitric oxide, sodium nitroprusside, peripheral blood lymphocytes, leukemic cells.

\section{INTRODUCTION}

Acute leukemia is a high-risk fast-proliferating cancer, which is associated with clonal proliferation and accumulation of abnormal cells derived from immature hematopoietic cells [16]. Current clinical strategy against childhood acute leukemia often employs combination of standard anticancer agents with asparaginase as a second line therapy [21]. This is because certain type of leukemia and lymphoma are auxotrophic for asparagine and thus susceptible to the treatment with recombinant asparaginase [23].

Pharmacological depletion of blood circulating free arginine is a promising strategy of modern metabolic anticancer therapy which may be applied for the treatment of blood cancers [20, 22, 24]. Currently, two recombinant arginine-degrading enzymes, bacterial arginine deiminase (ADI) and human arginase I (rhARG) have been proposed as anticancer therapeutics and evaluated in vitro and in animal and clinical trials [11, 20,

ISSN 1996-4536 (print) • ISSN 2311-0783 (on-line) • Біологічні Студії / Studia Biologica • 2016 • Том 10/№1 • C. 17-28 
24, 25, 31, 32]. Nevertheless, only arginine-auxotrophic tumors deficient in argininosuccinate synthetase (ASS), a rate-limiting enzyme of citrulline to arginine conversion in the urea cycle, are sensitive to a mono-treatment with recombinant arginine-degrading enzymes [6, 8]. It was shown that restriction of arginine using ADI is approximately 100 -fold more effective than asparagine restriction with L-asparaginase in inhibiting the proliferation of cultured human lymphoblastic leukemia cells and is less effective toward cells of myeloid origin [30]. As a less immunogenic alternative for ADI, rhARG is currently evaluated in laboratory, animal and clinical trials for the treatment of different types of cancer [17, 25, 32, 31]. Although arginine starvation was shown to be in general well tolerated, its depletion in the organism may nevertheless cause deficit in several of arginine metabolic derivatives, such as polyamines, creatine, neurotransmitters and nitric oxide (NO), and result in certain side effects [18]. NO is a multifunctional signalling molecule in the cell, which is synthesized from arginine by NO synthases (NOS) and regulates many important physiological processes, such as angiogenesis, platelet aggregation, blood pressure, vascular permeability, neurotransmission, wound healing and immune functions [10]. Thus, prolonged arginine depletion in humans may potentially initiate certain disorders involving vasoconstriction, thrombosis and functional impairment of immune system. Recent evidence suggests that, indeed, arginine deprivation leads to a decrease in intracellular NO production in macrophages in vitro and in vivo $[7,26]$. In ADI-treated patients, inhibition of endogenous NO occurred when plasma arginine levels dropped below the level of detection, but there was no increase in blood pressure or heart rate [1]. Of note, various studies showed that NO can either promote or inhibit tumor progression and metastasis in different cancer models [3, 10, 27].

In this study, we addressed the question whether and how exogenous NO donor, sodium nitroprusside (SNP), affects viability, growth potential and apoptosis of normal human peripheral blood lymphocytes (PBL) and leukemic cells under arginine deficiency specifically evoked by rhARG treatment. Our data suggest that a combination of rhARG with exogenous NO donor bears strong potential to be further developed as a new therapeutic approach against blood cancers.

\section{MATERIALS AND METHODS}

Cell lines and culture conditions. Jurkat leukemic cell line was obtained from Nencki Institute of Experimental Biology PAS (Warsaw, Poland). CEM-T4 and Namalva cell lines were obtained from cell culture collections at Kavetsky Institute of Experimental Pathology, Oncology and Radiobiology, NAS of Ukraine. Cells were cultured in RPMI 1640 medium supplemented with $10 \%$ fetal calf serum ("Sigma”, USA), 300 mg/l glutamine ("Sigma", USA) and $50 \mu \mathrm{g} / \mathrm{ml}$ gentamycin ("Sigma", USA) in a humidified $5 \%$ $\mathrm{CO}_{2}$ incubator at $37^{\circ} \mathrm{C}$.

Separation and cultivation of blood cells. PBL were isolated from heparinized whole blood of healthy donors and separated by density Histopaque 1077 according to instruction. Mononuclear cells were maintained in RPMI-1640 medium supplemented with $10 \%$ FBS, $300 \mathrm{mg} / \mathrm{L}$ glutamine and $50 \mu \mathrm{g} / \mathrm{mL}$ gentamycin in a humidified $5 \% \mathrm{CO}_{2}$ incubator at $37^{\circ} \mathrm{C}$. Proliferation of T lymphocytes was induced by incubation of PBL with $0.5 \mu \mathrm{g} / \mathrm{mL}$ phytohaemagglutinin (PHA, "Sigma", USA) and $20 \mathrm{U} / \mathrm{ml}$ recombinant interleukin 2 (rIL-2, "Millipore Corp.", USA) in culture medium for 4 days. Resting PBL were cultured in the presence of $20 \mathrm{U} / \mathrm{mL}$ rlL-2 only. Resting and proliferatively active PBL were used in the experiments.

ISSN 1996-4536 (print) • ISSN 2311-0783 (on-line) • Біологічні Студії / Studia Biologica • 2016 • Том 10/№1 • C. 17-28 
Trypan blue dye exclusion assay. The dynamics of cell growth was determined by trypan blue exclusion test. Briefly, cells were plated in 96-well plates at a density of $3-5 \times 10^{4}$ in RPMI 1640 medium and treated with $2 \mathrm{U} / \mathrm{ml}$ of the purified human recombinant arginase (rhARG, constructed and purified at the Department of Cell Signaling, ICB, NAS of Ukraine) and/or sodium nitroprusside (SNP, "Sigma", USA) for 24, 48 and 72 hours. Then cells were resuspended and aliquots of the cells were mixed with the trypan blue dye solution ("Sigma", USA) at its final concentration of $0.05 \%$. The cells were counted on a hemocytometer by light microscopy and stained blue cells were considered and calculated as "non-viable".

MTT assay. Concentration- and time-dependent SNP cytotoxicity was determined using the standard MTT assay. Cells were grown in 96-well plates with $0,0.01,0.1$, 1 and $10 \mathrm{mmol} / \mathrm{l}$ of SNP in either complete medium (CM) or the CM with $2 \mathrm{U} / \mathrm{ml}$ rhARG. After different treatments, $20 \mu \mathrm{L}$ of $5 \mathrm{mg} / \mathrm{mL}$ MTT solution ("Sigma", USA) was added to each well $(0.1 \mathrm{mg} /$ well $)$ and incubated for $5 \mathrm{~h}$. The supernatants were aspirated, the purple formazan crystals in each well were dissolved in $200 \mu \mathrm{L}$ of dimethyl sulfoxide and optical density at $540 \mathrm{~nm}$ was read on a Microplate Reader ("Biotek", USA). The amount of SNP needed to kill $50 \%$ of the cells in a culture was defined as the SNP inhibitory concentration (IC50).

Western blot analysis. Cells were lysed in extraction buffer containing $10 \mathrm{mM}$ Tris- $\mathrm{HCl}$ (pH 7.5), $150 \mathrm{mM} \mathrm{NaCl}, 1 \% \mathrm{NP}-40,5 \mathrm{mM}$ EDTA, $50 \mathrm{mM} \mathrm{NaF}, 1 \mathrm{mM} \mathrm{Na}_{3} \mathrm{VO}_{4}$, $5 \mathrm{mM}$ benzamidine, $1 \mathrm{mM}$ PMSF, $10 \mathrm{mg} / \mathrm{ml}$ aprotinin, $10 \mathrm{mg} / \mathrm{ml}$ leupeptin, $1 \mathrm{mg} / \mathrm{ml}$ pepstatin) at $4{ }^{\circ} \mathrm{C}$ for $20 \mathrm{~min}$. Protein content in the extracts that were obtained was determined according to Peterson's method [19]. For western blot analysis proteins were separated on $10 \%$ SDS-PAGE and transferred onto a PVDF membrane ("Millipore Corporation", USA). The membranes were blocked in $5 \%$ non-fat dried milk in PBS containing $0.05 \%$ Tween-20 and incubated with primary antibodies specific for the cleaved poly (ADP ribosyl) polymerase (PARP; "Cell Signaling Technologies", USA) and $\beta$-actin ("Sigma", USA) as the loading control. Secondary goat anti-mouse and anti-rabbit ("Millipore Corp.", USA) antibodies and an enhanced chemiluminescence system ("Millipore Corp.", USA) were used for the detection of immunoreactive proteins.

Apoptosis detection. Cells were resuspended in Ringer solution with calcium ions to a final concentration of $1 \times 10^{6} / \mathrm{ml}$. Then $5 \mu$ of cells suspension was mixed with $5 \mu \mathrm{L}$ of Annexin V-FITC ("Sigma", USA, final concentration $3 \mu \mathrm{g} / \mathrm{mL}$ ) followed by propidium iodide (final concentration $0.5 \mu \mathrm{g} / \mathrm{mL}$ ) as a counter stain. The cells were then incubated at room temperature for 5-15 min in the dark. Finally, the cells were covered with a coverslip and examined by fluorescent microscopy (Carl Zeiss, Germany). The percentage of apoptotic cells was calculated using ImageJ software.

Statistical analysis. All experiments were repeated at least three times. Levels of significant differences between groups were determined by the Student's $t$-test. $P$ values less then 0.05 were considered statistically significant.

\section{RESULTS AND DISCUSSION}

Arginine deprivation enhances SNP cytotoxicity for leukemic cells. In our previous study we found that SNP, a NO donor, does not counteract apoptotic cell death and, in fact, increases cytotoxic effect of arginine deprivation for Jurkat leukemic cells in defined arginine-free medium [5]. We also demonstrated that rhARG treatment alone is relatively harmless for normal PBL [4].

ISSN 1996-4536 (print) • ISSN 2311-0783 (on-line) • Біологічні Студії / Studia Biologica • 2016 • Том 10/№1 • С. 17-28 
Herein, we aimed to investigate how efficient can be combined rhARG and SNP treatment against leukemic cells of different origin. Three human leukemia cell lines were used as models for acute T- (Jurkat and CEM-T4) and B-cell (Namalva) leukemias. As control cells, we aplied primary isolated resting and PHA-activated human PBL from healthy donors. First, we examined cytotoxic and cytostatic effects of exogenous NO donor drug on normal and leukemic cells under arginine limitation. For this purpose, cells were treated with several increasing concentrations of $\operatorname{SNP}(0.01,0.1,1$ and $10 \mathrm{mmol} / \mathrm{l})$, either alone or in combination with purified rhARG in concentration of $2.0 \mathrm{U} / \mathrm{mL}$. The SNP cytotoxic concentration (IC50) for leukemic and PBL cells upon different culture conditions were performed by the MTT assay. We showed that SNP cytotoxicity grew in a dose- and time-dependent manner and was considerably enhanced by arginine restriction (Fig. 1). At 24, 48, and $72 \mathrm{~h}$, the SNP IC50 in normal medium for leukemic cells were approximately similar in 2-5 mM range for Jurkat, CEM-T4, and Namalva cells (Table 1). As shown in Fig. 1 and Table 1, in the medium with rhARG, SNP mediated cytotoxicity increased and IC50 at $72 \mathrm{~h}$ were significantly 3-7 times lower compared to IC50 values in complete medium (CM) and ranged between 0.4 and $1 \mathrm{mM}$ for the three cell lines tested $(p<0.05)$. Of note, Namalva cells appeared to be more resistant to SNP, which may be associated with their B-cell origin. However, why exogenous NO is more cytotoxic for non-proliferating arginine-deprived than for proliferating in the $\mathrm{CM}$ cancer cells remains to be elucidated. It is necessary to stress that similar effect was observed in our previous study on Jurkat cells incubated in defined arginine-free medium [5].

We next analyzed the SNP IC50 values for PBL in the same experimental conditions. Surprisingly, we observed that experimental normal cells were in general more sensitive to SNP as compared to malignant cells. Interestingly, SNP IC50 values for resting $P B L$ did not differ drastically between control medium and medium with rhARG (Fig. 1, Table). However, as also shown in Fig. 1, SNP-mediated cytotoxicity significantly differed (were lower) for the activated PBL in complete medium, as compared to resting cells $(p<0.05)$. In contrast to leukemic cells, either proliferatively active or resting PBL were more sensitive to SNP treatment in complete medium.

Taken together, these data suggest, that nitric oxide donor is more toxic toward normal PBL, specially for proliferatively active PBL, but synergistically increases arginasemediated arginine deprivation cytotoxicity selectively for leukemic cells. Of note, SNP in very low concentrations (below $100 \mu \mathrm{M}$ ) that was proposed as therapeutic dose [5] was non-toxic for resting immune cells.

Low dose NO potentiates the arginine deprivation-mediated cytotoxicity against proliferatively active cells. NO-releasing compounds such as SNP are widely used to investigate the effects of NO on various physiological processes and molecular mechanisms of the cell [15]. In SNP, NO is coordinated as a nitrosyl group ligated to iron in a square bipyramidal complex, and is released spontaneously at physiological $\mathrm{pH}$ in one step reaction [13]. It was shown that $\mathrm{NO}$ formation in vivo is accompanied by cyanide $\left(\mathrm{CN}^{-}\right)$release which is rapidly metabolized by the liver to thiocyanate that is next released by the kidneys. However, despite its apparent toxicity, SNP is a popular drug, most effective in some difficult clinical circumstances [12].

To better clarify the role of NO and cyanide in SNP-mediated cytotoxic and cytostatic activity, we investigated the effects of potassium ferricyanide $\left(\mathrm{K}_{3}\left[\mathrm{Fe}(\mathrm{CN})_{6}\right]\right)$ and sodium thiosulphate $\left(\mathrm{Na}_{2} \mathrm{~S}_{2} \mathrm{O}_{3}\right)$ as controls for the ferricyanide or cyanide moieties released by SNP [29]. As shown in Fig. 2, F vs $A, 1$ mM SNP caused significant growth

ISSN 1996-4536 (print) • ISSN 2311-0783 (on-line) • Біологічні Студії / Studia Biologica • 2016 • Том 10/№1 • C. 17-28 


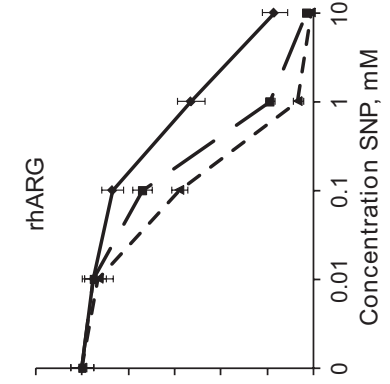

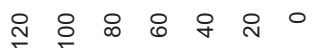

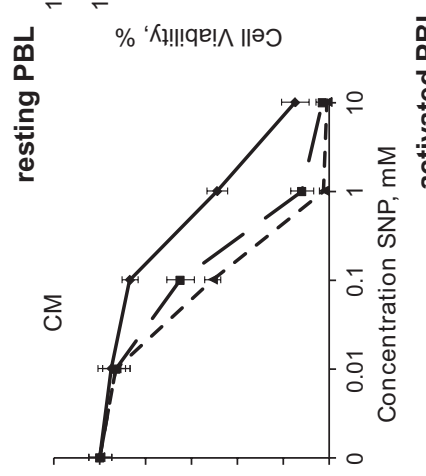

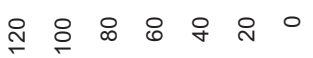

\% ‘র!!!!q!!^ ॥əว

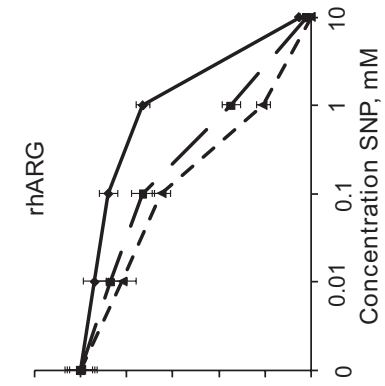

용 8 \& 8 \%

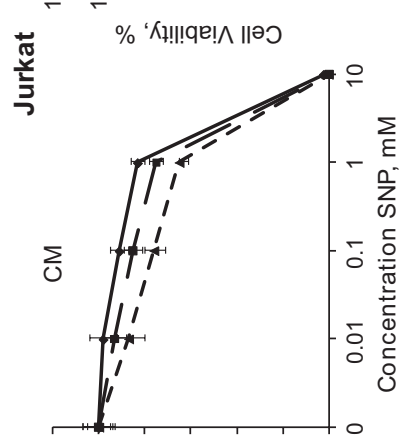

은 8 : 8 우 0

\% 'Kł!!!qu!^ ||əว
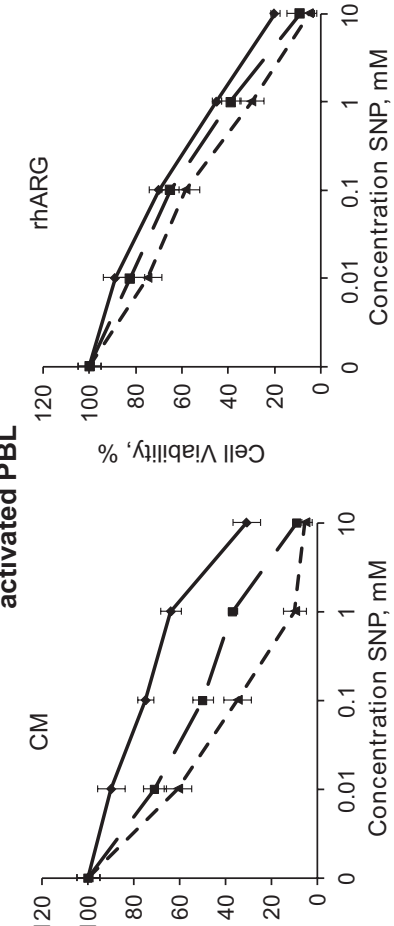

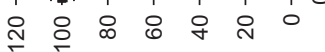

\% 'Кㄴ!!!qE!^ ||əว

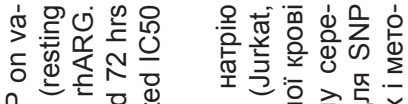

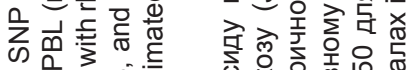

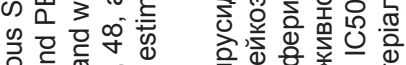

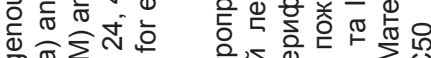

बำ

×

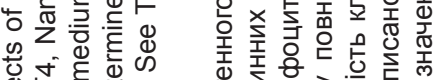

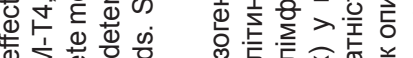

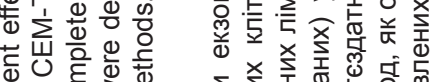

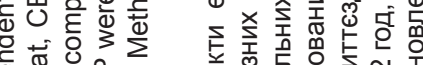

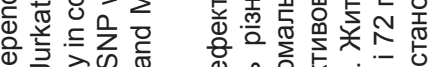

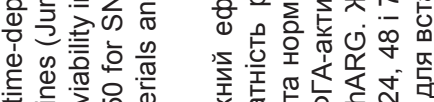

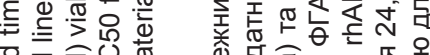

등 $\overline{\bar{d}} \mathrm{~d}$ 元

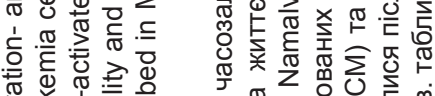

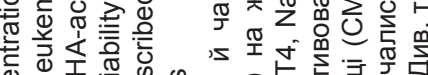

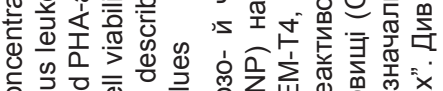

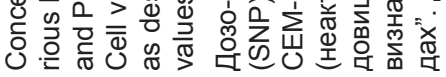

宅
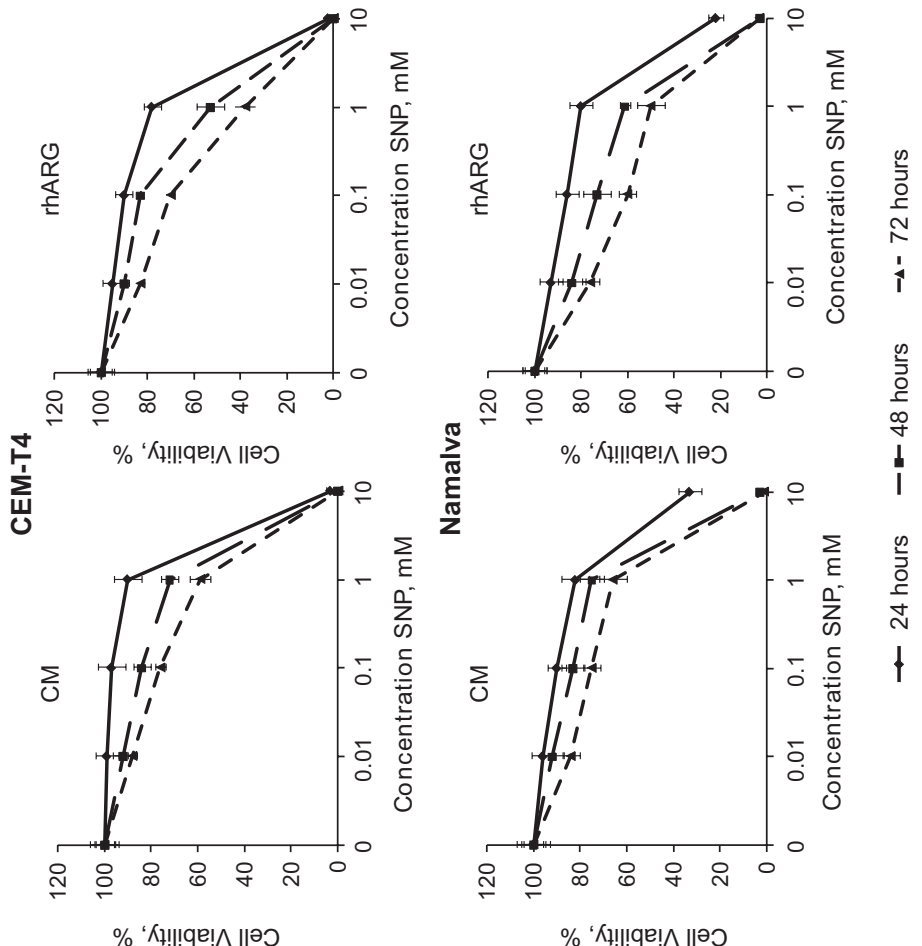

ISSN 1996-4536 (print) • ISSN 2311-0783 (on-line) • Біологічні Студії / Studia Biologica • 2016 • Том 10/№1 • C. 17-28 
inhibition of Jurkat cells $(p<0.05)$. Nevertheless, potassium ferricyanide (which is structurally similar to SNP except for the absence of a nitroso group) did not inhibit cell growth at the same concentration. Trypan blue exclusion indicated $95 \%$ of viable Jurkat cells at $72 \mathrm{~h}$ after treatment with $1 \mathrm{mM} \mathrm{K}_{3}\left[\mathrm{Fe}(\mathrm{CN})_{6}\right]$ alone. Also, the cytotoxicity elicited by SNP was not abolished when cells were co-incubated with $1 \mathrm{mM}$ sodium thiosulphate - a substance known to bind $\mathrm{CN}^{-}$moiety (Fig. 2, F) [15]. According to this data, we suggest that only NO released by SNP is responsible for modulation of viability of experimental model cells used herein

The cytotoxicity of SNP for leukemic cell lines and PBL. The inhibitory concentration of 50 $\%($ IC50, mM) values were measured by MTT assay after 24,48 and $72 \mathrm{~h}$ of the SNP treatment in complete medium (CM) and medium with rhARG

Цитотоксичність SNP для клітинних ліній лейкозу та нормальних лімфоцитів периферичної крові (PBL). Інгібіторну концентрацію SNP (IC50, мM) визначали за допомогою MTT-тесту після 24, 48 та 72 годин інкубування з SNP на повному середовищі (CM) і середовищі 3 rhARG

\begin{tabular}{cccc} 
Cells & Time, hrs & CM & CM + rhARG \\
\hline \multirow{3}{*}{ Jurkat } & 24 & $4.7 \pm 0.3$ & $4.0 \pm 0.2$ \\
& 48 & $4.0 \pm 0.2$ & $0.7 \pm 0.1$ \\
& 72 & $3.0 \pm 0.3$ & $0.4 \pm 0.1$ \\
CEM-T4 & 24 & $5.1 \pm 0.3$ & $4.3 \pm 0.3$ \\
& 48 & $3.6 \pm 0.2$ & $1.5 \pm 0.2$ \\
& 72 & $2.2 \pm 0.1$ & $0.7 \pm 0.1$ \\
\hline \multirow{2}{*}{ Namalva } & 24 & $6.3 \pm 0.3$ & $5.5 \pm 0.3$ \\
& 48 & $4.2 \pm 0.4$ & $2.6 \pm 0.2$ \\
activated PBL & 72 & $3.3 \pm 0.2$ & $1.0 \pm 0.1$ \\
& 24 & $3.8 \pm 0.3$ & $1.2 \pm 0.1$ \\
& 48 & $0.3 \pm 0.06$ & $0.6 \pm 0.04$ \\
resting PBL & 72 & $0.06 \pm 0.02$ & $0.4 \pm 0.03$ \\
& 24 & $1.5 \pm 0.1$ & $1.2 \pm 0.1$ \\
& 48 & $0.5 \pm 0.06$ & $0.4 \pm 0.05$ \\
& 72 & $0.3 \pm 0.03$ & $0.2 \pm 0.04$ \\
\hline
\end{tabular}

We further examined in more details the dynamics of viability of model cells under rhARG-mediated arginine starvation alone or in combination with low dose SNP in trypan blue dye exclusion assay. We have chosen one maximally tolerated dose of SNP $(0.05 \mathrm{mM})$ that did not produce any apparent and unacceptable cytotoxicity in both arginine-containing and arginine-free media for normal resting PBL according to the obtained IC 50 values (Table). It is estimated by monitoring nitrite accumulation $0.05 \mathrm{mM}$ SNP releases up to $20-30 \mu \mathrm{M}$ of NO into the culture medium, the level compatible with physiologically observed in blood plasma (30-70 $\mu \mathrm{M})[5,9]$.

As was expected, none of the cell lines incubated with rhARG up to $72 \mathrm{~h}$ exhibited significant growth (Fig. 2, A-C). As shown in Fig. $2 D$, rhARG significantly inhibited proliferation of PHA-activated PBL but did not drastically decrease cell viability $(p<0.05)$. Also, arginine restriction by rhARG had no effect on normal resting $P B L$ viability

ISSN 1996-4536 (print) • ISSN 2311-0783 (on-line) • Біологічні Студії / Studia Biologica • 2016 • Том 10/№1 • C. 17-28 

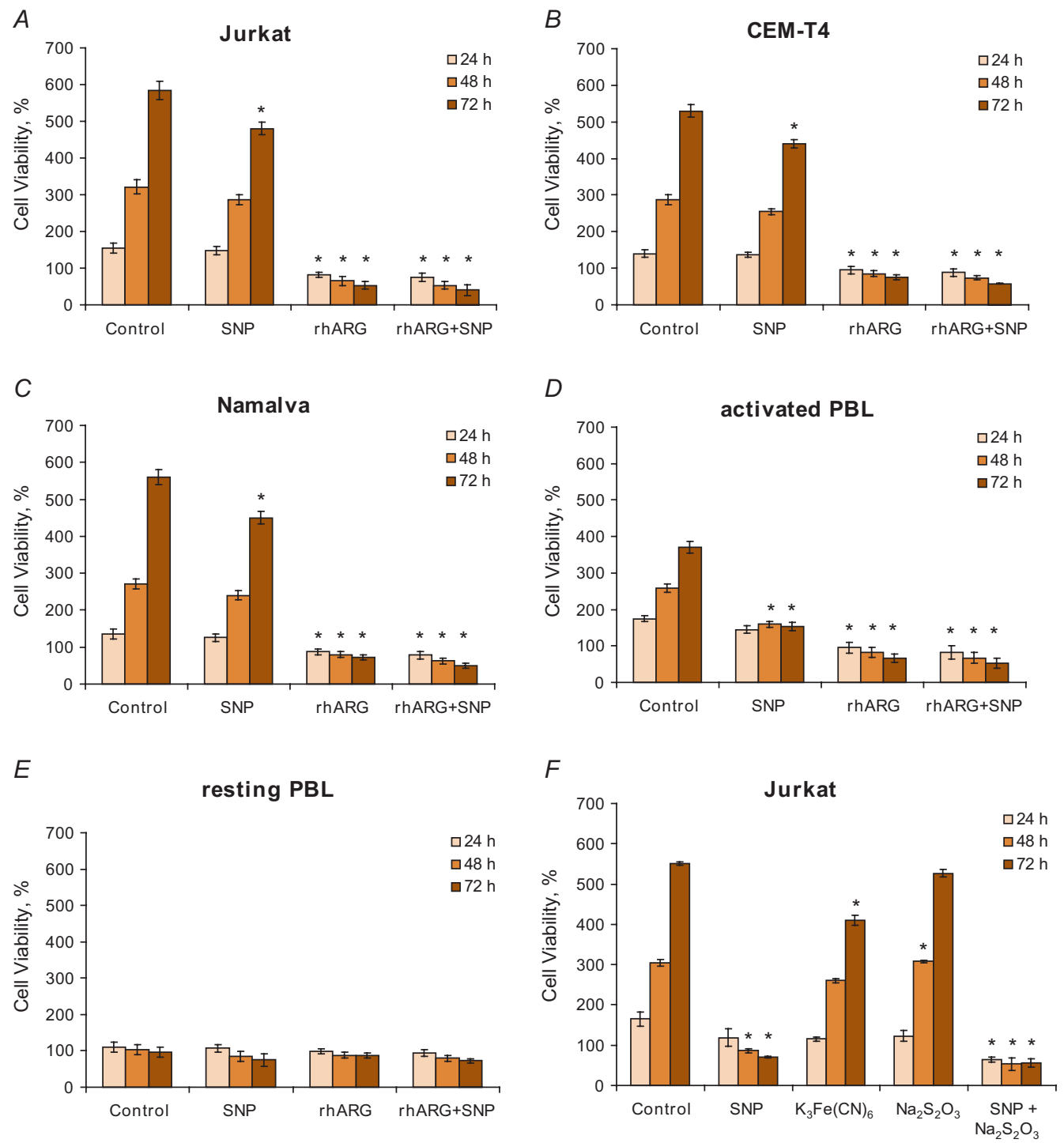

Fig. 2. Effect of combined rhARG and SNP treatment on viability of Jurkat $(\boldsymbol{A})$, CEM-T4 (B), Namalva (C) leukemic cells and PHA-activated $(\boldsymbol{D})$ and resting PBL $(\boldsymbol{E})$ in $\mathrm{CM}$; CM + $0.05 \mathrm{mM}$ SNP; CM + rhARG $(2 \mathrm{U} / \mathrm{mL})$; and $\mathrm{CM}+$ rhARG $+0.05 \mathrm{mM}$ SNP. $\boldsymbol{F}$ - cytotoxic effect of elevated $1 \mathrm{mM}$ SNP, nitrite or ferrocyanide on Jurkat cells. Cell quantifications were conducted by the trypan blue exclusion test for 24 , 48,72 hrs of the treatments. ${ }^{*} p \leq 0.05$ as compared with the untreated cells

Pис. 2. Спільний вплив rhARG та SNP на життєздатність клітинних ліній лейкозу Jurkat $(\boldsymbol{A})$, CEM-T4 (B), Namalva $(\boldsymbol{C})$ і ФГА-активованих $(\boldsymbol{D})$ та неактивованих PBL $(\boldsymbol{E})$ у CM; CM + 0.05 мM SNP; CM + rhARG (2 Од./мл) та CM + rhARG + 0.05 MM SNP. $\boldsymbol{F}$ - Цитотоксичний ефект підвищеної до 1 мM концентрації SNP, нітриту чи фероціаніду на клітини лейкозу Jurkat. Підрахунок клітин проводили у тесті з трипановим синім через 24, 48 та 72 год після додавання досліджуваних речовин. * $p \leq 0,05$ різниця достовірна порівняно з необробленими клітинами 
(Fig. 2, E). SNP at $0.05 \mathrm{mM}$ concentration had no effect on leukemic cells growth (only slightly suppressed proliferation in complete medium; Fig. 2, A-C), but significantly suppressed PHA-stimulated proliferation of PBL (Fig. 2, D; p<0.05). In turn, as shown in Fig. 2, incubation of leukemic cells and PHA-activated PBL with $0.05 \mathrm{mM}$ SNP in the presence of rhARG caused some decrease in cell viability. Jurkat T-lymphoblastic leukemia was more sensitive to this combinational treatment (Fig. 2, A). However, there was no statistically significant difference observed in the amount of viable cells in resting PBL (Fig. 2, E) under the combined treatment $(p<0.05)$. Thus, low dose of SNP slightly, but evidently enhanced cytotoxicity of rhARG for all proliferatively active cells. Normal resting PBL were highly resistant to the combined drugs action.

A

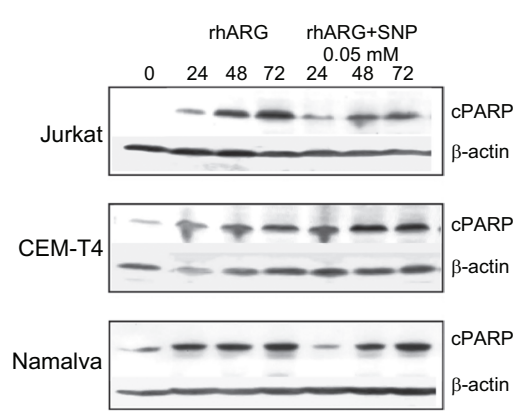

$B$

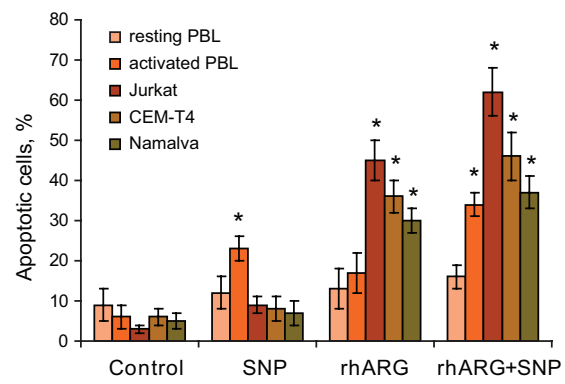

C
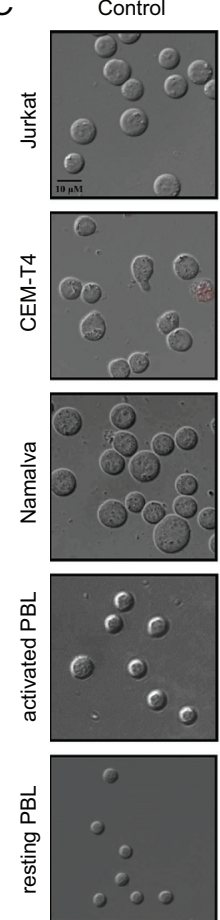

SNP
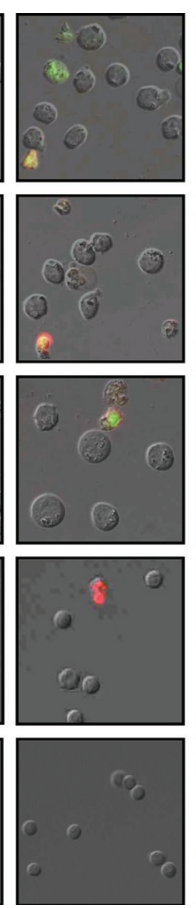

$\operatorname{rhARG}$
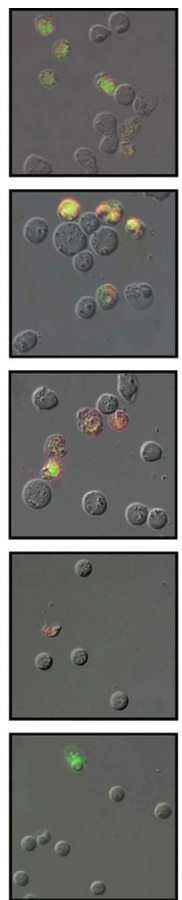

rhARG+SNP
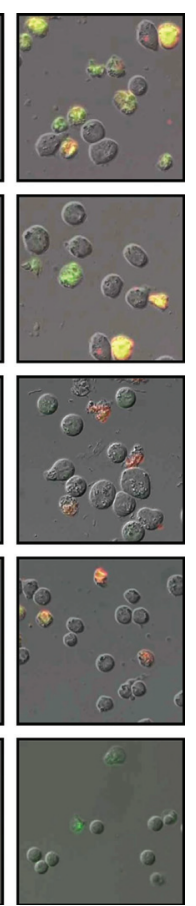

Fig. 3. $\boldsymbol{A}$ - Western blot analysis of the cleaved PARP protein in leukemic cell lines cultured in medium with rhARG $(2 \mathrm{U} / \mathrm{ml})$ or in medium with rhARG and SNP $(0.05 \mathrm{mM})$. $\boldsymbol{B}$ - Effect of the combined rhARG and SNP treatment on progression of apoptosis in normal and leukemic cells. Cells were stained with Annexin V-FITC and propidium iodide (PI) and analyzed by fluorescence microscopy as described in Materials and Methods, ${ }^{*} \mathrm{p} \leq 0.05$ compared with untreated cells. $\boldsymbol{C}$ - Merged image of Annexin V-FITC /PI fluorescence of normal and leukemic apoptotic cells: Control - control cells, cultured in the complete medium; rhARG - cells, cultured with rhARG $(2 \mathrm{U} / \mathrm{ml})$; SNP - cells treated with $0.05 \mathrm{mM} \mathrm{SNP}$; rhARG+SNP - cells treated with rhARG and $0.05 \mathrm{mM}$ SNP

Рис. 3. $\boldsymbol{A}$ - Вестерн-блот-аналіз розщепленої форми PARP протеїну в клітинних лініях лейкозу, які культивували в середовищі з rhARG (2 Од./мл) або в середовищі з rhARG i SNP (0,05 мм). В - Комбінований вплив rhARG і SNP на запуск апоптозу в нормальних і лейкозних клітинах. Клітини фарбували анексином V-FITC та пропідій йодидом (PI) і аналізували за допомогою флуоресцентної мікроскопії, як описано в “Матеріалах і методах". " $p \leq 0,05$ різниця достовірна порівняно з необробленими клітинами. $\boldsymbol{C}$ - Накладені зображення анексин V-FITC/PI фрлуоресценції нормальних і лейкозних апоптичних клітин: Контроль - контрольні клітини, культивовані в СМ; rhARG - клітини, культивовані з rhARG (2 Од./мл), SNP - клітини, оброблені 0,05 мM SNP; rhARG+SNP - клітини, оброблені rhARG і 0,05 мM SNP

ISSN 1996-4536 (print) • ISSN 2311-0783 (on-line) • Біологічні Студії / Studia Biologica • 2016 • Том 10/№1 • C. 17-28 
Arginase and SNP treatment induces apoptosis selectively in leukemic cells. To better understand the mechanism of leukemic cell sensitivity to the combined rhARG and SNP treatment, apoptosis progression in malignant cells and PBL was investigated. During induction of apoptosis, as a target of active caspase-3, PARP to be cleaved into two fragments [14]. We therefore analyzed the appearance of cleaved form of PARP (poly(ADPribosyl)-polymerase) protein by western blotting. It was observed that rhARG treatment induced time-dependent apoptosis in three leukemic cell lines (Fig. 3, A). Importantly, supplementation with $0.05 \mathrm{mM}$ SNP had no significant inhibitory effect on this process. This data was also corroborated by cells double staining with fluorochromes Annexin V-FITC (binds to phosphatidylserine on membranes of apoptotic cells) and propidium iodide (Fig. 3, $B, C$ ). It was shown that rhARG treatment induced morphological changes in leukemic cells such as cell shrinkage, nuclear condensation and phosphatidylserine externalization, which are typical hallmarks of apoptosis (Fig. 3, C). We observed a higher number of apoptotic cells upon $72 \mathrm{~h}$-long rhARG treatment (Fig. 3, B) only for tested leukemic cell lines (30-46\%, $p<0.05)$. Compared to rhARG treated values alone, the percentage of apoptotic cells considerably increased under both rhARG and SNP treatment (37-62 \%). Importantly, there were no significant alterations in the number of apoptotic cells in normal resting PBL under all treatments: only spontaneous apoptosis was detected under both rhARG and Cav treatment (9$16 \%$; p 0.05). As shown in Fig. $3 \mathrm{~B}, \mathrm{C}$, minimal signs of apoptosis in PHA-activated $\mathrm{PBL}$ were observed after $72 \mathrm{~h}$ incubation of these cells in culture with rhARG alone $(17 \%)$. In agreement with cytotoxicity data above, the percentage of apoptotic cells significantly increased (34 \%) under combinatory rhARG and SNP treatment in PHAactivated PBL. According to this data, we hypothesize that NO deficiency resulting from arginine deprivation is not the primary cause of high leukemic cells sensitivity to rhARG. In the opposite case, exogenous NO would rescue leukemic cells viability upon arginase treatment. This and other our studies on different cell models also support the notion that not arginine metabolism but other cell response signaling mechanisms must be potentially involved in determining cell fate upon arginine restriction $[2,28]$.

\section{CONCLUSION}

In summary, we described novel pre-clinical in vitro experiments for evaluation of the effect of NO-donor SNP on normal and leukemic cells under arginine deprivation. It was demonstrated that rhARG fully inhibited cell proliferation and decreased viability of all tested human leukemia cell lines and activated PBL but had no significant effect on viability and apoptosis of resting cells. It was shown that rhARG induced apoptosis more selectively and effectively in leukemic cells compared to normal PBL. Exogenous NO was more toxic for proliferatively active PBL, but synergistically increased rhARG cytotoxicity selectively for leukemic cells. We suggest that arginine-degrading enzymotherapy bears clinical potential for leukemia treatment and low doses of SNP can be recommended as a compensatory agent under arginine limitation in vivo.

\section{ACKNOWLEDGEMENTS}

This work was partially supported by personal grant to O. Chen from West-Ukrainian Biomedical Research Center (WUBMRC) in 2011-2012. 
1. Ascierto P.A., Scala S., Castello G. et al. Pegylated arginine deiminase treatment of patients with metastatic melanoma: results from phase I and II studies. J. Clin. Oncol, 2005; 23: 7660-7668.

2. Bobak Y.P., Vynnytska B.O., Kurlishchuk Y.V. et al. Cancer cell sensitivity to arginine deprivation in vitro is not determined by endogenous levels of arginine metabolic enzymes. Cell Biol. Int, 2010; 34:1085-89.

3. Burke A.J., Sullivan F.J., Giles F.J., Glynn S.A. The yin and yang of nitric oxide in cancer progression. Carcinogenesis, 2013; 34(3): 503-512.

4. Chen O., Kavalets B., Barska M. et al. Effect of combinational arginase and canavanine treatment on normal human peripheral blood lymphocytes in vitro. Curr. Issues Pharm. Med. Sci, 2013; 26(4): 385-389.

5. Chen O.I., Lyniv L.S., Igumentseva N.I. et al. Effect of nitric oxide donor on viability of human leukemic cells upon arginine deprivation. Studia Biologica, 2011; 5(2): 17-28.

6. Delage B., Fennell D.A., Nicholson L. Arginine deprivation and argininosuccinate synthetase expression in the treatment of cancer. Int. J. Cancer, 2010; 126: 2762-2772.

7. Dillon B.J., Holtsberg F.W., Ensor C.M. et al. Biochemical characterization of the arginine degrading enzymes arginase and arginine deiminase and their effect on nitric oxide production. Med. Sci Monit, 2002; 8(7): 248-253.

8. Feun L., You M., Wu C.J. Arginine deprivation as a targeted therapy for cancer. Curr. Pharm. Des, 2008; 14: 1049-1057.

9. Fujiwara N., Osanai T., Kamada T. et al. Study on the relationship between plasma nitrite and nitrate level and salt sensitivity in human hypertension: modulation of nitric oxide synthesis by salt intake. Circulation, 2000; 101: 856-861.

10. Fukumura D., Kashiwagi S., Jain R.K. The role of nitric oxide in tumor progression. Nature Reviews Cancer, 2006; 6: 521-534.

11. Glazer E.S., Stone E.M., Zhu C. et al. Phase II study of pegylated arginine deiminase for nonresectable and metastatic hepatocellular carcinoma. J. Clin. Oncol, 2010; 28(13): 2220-2226.

12. Hottinger D.G., Beebe D.S., Kozhimannil T. et al. Sodium nitroprusside in 2014: A clinical concepts review. J. Anaesthesiol. Clin. Pharmacol, 2014; 30(4): 462-471.

13. Ivankovich A.D., Miletich D.J., Tinker J.H. Sodium nitroprusside: metabolism and general considerations. Int. Anesthesiol. Clin, 1978; 16: 1-29.

14. Koh D.W., Dawson T.M., Dawson V.L. Mediation of cell death by poly(ADP-ribose) polymerase-1. Pharmacol Res, 2005; 52(1): 5-14.

15. Lockwood A., Patka J., Rabinovich M. et al. Sodium nitroprusside-associated cyanide toxicity in adult patients - fact or fiction? A critical review of the evidence and clinical relevance. Open Access Journal of Clinical Trials, 2010; 2: 133-148.

16. Loh M.L., Mullighan C.G. Advances in the genetics of high-risk childhood B-progenitor acute lymphoblastic leukemia and juvenile myelomonocytic leukemia: implications for therapy. Clin. Cancer Res, 2012; 18: 2754-2768.

17. Mauldin J.P., Zeinali I., Kleypas K. et al. Recombinant human arginase toxicity in mice is reduced by citrulline supplementation. Transl. Oncol, 2012, 5(1): 26-31.

18. Morris S.M. Arginine: beyond protein. Am. J. Clin. Nutr, 2006; 83 (Suppl): 508-512.

19. Peterson G.L. A simplification of the protein assay method of Lowry et al. which is more generally applicable. Anal. Biochem, 1977; 83: 346-356.

20. Phillips M.M., Sheaff M.T., Szlosarek P.W. Targeting arginine-dependent cancers with arginine-degrading enzymes: opportunities and challenges. Cancer Res. Treat, 2013; 45(4): 251-262.

21. Pieters R., Appel I., Kuehnel H.J. et al. Pharmacokinetics, pharmacodynamics, efficacy, and safety of a new recombinant asparaginase preparation in children with previously untreated acute lymphoblastic leukemia: a randomized phase 2 clinical trial. Blood, 2008; 112: 4832 4838 .

ISSN 1996-4536 (print) • ISSN 2311-0783 (on-line) • Біологічні Студії / Studia Biologica • 2016 • Том 10/№1 • C. 17-28 
22. Qiu F., Huang J., Sui M. Targeting arginine metabolism pathway to treat arginine-dependent cancers. Cancer Letters, 2015; 364(1): 1-7.

23. Rytting M.E. Role of L-asparaginase in acute lymphoblastic leukemia: focus on adult patients. Blood and Lymphatic Cancer: Targets and Therapy, 2012; 2: 117-124.

24. Stasyk O.V., Boretsky Yu. R., Gonchar M.V., Sibirny A.A. Recombinant arginine-degrading enzymes in metabolic anticancer therapy and bioanalytics. Cell Biol. Int, 2015; 39: 246-252.

25. Tanios R., Bekdash A., Kassab E. et al. Human recombinant arginase I (Co)-PEG5000 [HuArgl(Co)-PEG5000]-induced arginine depletion is selectively cytotoxic to human acute myeloid leukemia cells. Leukemia Res, 2013; 37(11): 1565-71.

26. Thomas J.B., Holtsberg F.W., Ensor C.M. et al. Enzymic degradation of plasma arginine using arginine deiminase inhibits nitric oxide production and protects mice from the lethal effects of tumour necrosis factor a and endotoxin. Biochem. J, 2002; 363: 581-587.

27. Villalobo A. Nitric oxide and cell proliferation. FEBS, 2006; 273: 2329-2344.

28. Vynnytska B.O., Mayevska O.M., Kurlishchuk Y.V. et al. Canavanine augments proapoptotic effects of arginine deprivation in cultured human cancer cells. Anticancer Drugs, 2011; 22(2): 148-57.

29. Wang P.G., Xian M., Tang $X$. et al. Nitric oxide donors: chemical activities and biological applications. Chem. Rev, 2002; 102: 1091-1134.

30. Wells J.W., Evans C.H., Scott M.C. et al. Arginase treatment prevents the recovery of canine lymphoma and osteosarcoma cells resistant to the toxic effects of prolonged arginine deprivation. PLOS ONE, 2013; 8(1): 1-9.

31. Yau T., Cheng P.N., Chan P. et al. A phase 1 dose-escalating study of pegylated recombinant human arginase 1 (Peg-rhArg1) in patients with advanced hepatocellular carcinoma. Invest. New Drugs, 2013; 31: 99-107.

32. Yoon J.K., Frankel A.E., Feun L.G. et al. Arginine deprivation therapy for malignant melanoma. Clin. Pharmacol, 2013; 5: 11-19.

\title{
КОМБІНОВАНИЙ ВПЛИВ АРГІНАЗИ І ДОНОРА ОКСИДУ АЗОТУ НА НОРМАЛЬНІ ТА ЛЕЙКОЗНІ КЛІТИНИ IN VITRO
}

\author{
О. І. Чень ${ }^{1,2}$, М. Л. Барська', Л. С. Линів ${ }^{1}$, \\ Н. І. Іеуменцева ${ }^{1}$, О. І. Вовк ${ }^{1}$, Н. О. Сибірна ${ }^{1,2}$, О. В. Стасик ${ }^{1 *}$ \\ ${ }^{1} /$ нститут біології клітини НАН України, вул. Драгоманова, 14/16, Львів 79005, Україна \\ ${ }^{2}$ Львівський національний університет ім. Івана Франка \\ вул. Грушевського, 4, Львів 79005, Україна \\ *e-mail: stasyk@cellbiol.Iviv.ua
}

Створення дефіциту аргініну відносно недавно було запропоноване як терапевтичний підхід у лікуванні певних типів раку крові. У цій роботі вперше досліджено комбінований вплив екзогенного донора оксиду нітрогену (NO) і рекомбінантної аргінази людини (rhARG) як ензиму деградації аргініну на життєздатність кількох клітинних ліній лейкозу людини та нормальних лімфоцитів периферичної крові. Виявлено, що екзогенний донор NO, нітропрусид натрію (SNP) у співмірній з фізіологічною концентрацією дозі не протидіяв, а посилював rhARG-опосередкований проапоптичний вплив голодування за аргініном на лейкозні клітини, на відміну від нормальних неактивованих лімфоцитів.

Отже, ми припускаємо, що дефіцит NO як результат голодування за аргініном не $є$ першопричиною високої чутливості лейкозних клітин до дії rhARG. Результати цього дослідження додатково підтверджують думку, що не катаболізм аргініну, 
а інші механізми клітинної відповіді залучені у визначення її загибелі за умов дефіциту аргініну. SNP або альтернативні донори NO можуть бути запропоновані як компоненти метаболічної антилейкозної терапії на основі голодування за аргініном.

Ключові слова: рекомбінантна аргіназа, оксид азоту, нітропрусид натрію, лімфоцити периферичної крові, клітини лейкозу.

\title{
КОМБИНИРОВАННОЕ ВОЗДЕЙСТВИЕ АРГИНАЗЫ И ДОНОРА ОКСИДА АЗОТА НА НОРМАЛЬНЫЕ И ЛЕЙКОЗНЫЕ КЛЕТКИ IN VITRO
}

\author{
О. И. Чень ${ }^{1,2}$, М. Л. Барская', Л. С. Лынив ${ }^{1}$, \\ Н. И. Игуменцева', О. И. Вовк', Н. А. Сибирная ${ }^{1,2}$, О. В. Стасык ${ }^{1 *}$ \\ ${ }^{1}$ Институт биологии клетки НАН Украины, ул. Драгоманова, 14/16, Львов 79005, Украина \\ 2 Львовский национальный университет имени Ивана Франко \\ ул. Грушевского, 4, Львов 79005, Украина \\ *e-mail: stasyk@cellbiol.Iviv.ua
}

Создание дефицита аргинина сравнительно недавно было предложено как терапевтический подход в лечении некоторых типов рака крови. В данной работе мы впервые исследовали комбинированное воздействие экзогенного донора оксида азота (NO) и рекомбинантной аргиназы человека (rhARG) как энзима деградации аргинина на жизнеспособность нескольких клеточных линий лейкоза человека и нормальных лимфоцитов периферической крови. Мы обнаружили, что экзогенный донор NO, нитропруссид натрия (SNP) в соизмеримой с фризиологической концентрацией дозе не препятствовал, а усиливал rhARG-опосредованное проапоптическое влияние голодания по аргинину на лейкозные клетки, в отличие от нормальных неактивированных лимфоцитов.

Таким образом, мы предполагаем, что дефицит NO как результат голодания по аргинину не является первопричиной высокой чувствительности лейкозных клеток к действию rhARG. Результаты этого исследования дополнительно подтверждают мнение, что не катаболизм аргинина, а другие механизмы клеточного ответа вовлечены в определение ее гибели в условиях дефицита аргинина. SNP или альтернативные доноры NO могут быть предложены в качестве компонентов метаболической антилейкозной терапии на основе голодания по аргинину.

Ключевые слова: рекомбинантная аргиназа, оксид азота, нитропруссид натрия, лимфоциты периферической крови, клетки лейкоза.

Одержано: 22.02.2016

ISSN 1996-4536 (print) • ISSN 2311-0783 (on-line) • Біологічні Студії / Studia Biologica • 2016 • Том 10/№1 • C. 17-28 